\title{
Production engineers profiling: competences of the professional the market wants
}

\author{
Flávia Roesler Cordeiro ${ }^{\mathrm{a}}$ (D), Carolline Amaral Paslauskia* (D), Priscila Wachs ${ }^{\mathrm{a}}$ (D), \\ Maria Auxiliadora Cannarozzo Tinoco ${ }^{\mathrm{a}}$ (i) \\ aUniversidade Federal do Rio Grande do Sul, Porto Alegre, RS, Brasil \\ *carollpaslauski@hotmail.com
}

\begin{abstract}
Paper aims: Identify the differences in the competences of the production engineering alumni and the importance attributed to it by the job market.

Originality: This is funded on investigating the gap between the competences the academy and the job market attribute to the professional of production engineering.
\end{abstract}

Research method: A questionnaire with production engineers was conducted to collect data that was analyzed using descriptive and predictive quantitative methods.

Main findings: Soft skills have higher importance to the job market but are the less addressed by universities. Professional competence importance is dependent on the sector. The skills with the higher gaps are associated with the constant transformation of industries and the increasing complexity of decision-making.

Implications for theory and practice: Theory should adopt a strategic orientation to guide the prioritization of competences and practice must adapt selection mechanisms to test for soft skills and customize it to the professional sector.

\section{Keywords}

Alumni monitoring. Competences prioritization. Reliability analysis. Gaps.

How to cite this article: Cordeiro, F. R., Paslauski, C. A., Wachs, P., \& Tinoco, M. A. C. (2020). Production engineers profiling: competences of the professional the market wants. Production, 30, e20190093. https://doi.org/10.1590/01036513.20190093

Received: Aug. 14, 2019; Accepted: Jan. 9, 2020.

\section{Introduction}

In an environment of constant change, higher education institutions must constantly renew themselves to offer courses relevant and appropriate to market needs (Deros et al., 2012). For this to happen, Jackson (2010) states that it is essential to continually verify and articulate the opinion of companies about what makes a course employable and ensure that undergraduate courses are aligned with the market. For this, the undergraduate alumni, that leaves the academy and is evaluated in the job market, is a key actor in the interplay between the fields of education and professional performance (Instituto Nacional de Estudos e Pesquisas Educacionais Anísio Teixeira, 2015).

In this context, just as companies build relationships with their clients, universities seek to establish relationships and strengthen ties with their alumni in order to leverage financial and nonfinancial contributions that these professionals can provide to the institution (Heckman \& Guskey, 1998). For this, some universities develop a follow-up of the alumni path that contributes to the dissemination of technology and builds a feedback loop of alumni that ensures the institution's sustainable educational development (Brudler \& Holtorf, 2018).

In practice, the evaluation performed by the alumni presents what was developed in the course, what is used in the professional environment and what was not covered in the course, but is required in the job market 
(Instituto Nacional de Estudos e Pesquisas Educacionais Anísio Teixeira, 2015). This evaluation process helps in improving the quality and in meeting the society's demands by the institution (Silva \& Bezerra, 2015).

Assessing the adequacy of the course to the job market demands can be conducted by identifying gaps between competences required by the job market and those developed during the undergraduate course. According to Passow (2012), it is important to list the competences required for the professional performance of the graduate and assess the importance of each of them. This initiative contributes to the institution's development and adaptation through a complementary evaluation of higher education, using multiple perspectives that allow a better understanding of the complexity involved in this context (Ribeiro, 2014).

Monitoring the trajectory and perception of professional alumni from the undergraduate course is a fundamental tool to know the alumni's profile (Silva \& Bezerra, 2015) and to analyze the competences expected and acquired by the professional during its graduation. The formation of an alumni network that allows the collection of feedback begins by collecting and registering the alumni information. These records present data about personal and professional life, as well as the evaluation of the institution by the alumni.

In the case of an undergraduate degree in production engineering (or industrial engineering), the alignment between market and academia is especially necessary given that, according to Associação Brasileira de Engenharia de Produção (1998), the success of Brazilian companies is related to the study and practices related to the course. In addition, due to its role in innovation development and management, the production engineering professional is one of the first to feel the impact of technological and market changes (Borchardt et al., 2009). To this end, educational institutions must be able to constantly respond "which is the gap between the competences developed in professionals graduating from the production engineering course and what are the competences demanded by the market regarding this professiona?" and this work engages in this as its research question.

At this scenario, this article aims to achieve three specific objectives: i) map the profile of production engineering course alumni, through personal and professional information; ii) identify gaps in the perception of alumni between the importance of production engineer competences and how much those were developed during the course; iii) correlate profile information of graduates with the competence gaps evaluated by them. From these, the main objective is to establish the competences universities should aim to develop the production engineer of the future.

\section{Theoretical background}

\subsection{The benefits of the bond between the alumni and the higher education institution}

Alumni relationship management is an essential initiative for any university (Rattanamethawong et al., 2018) and the contributions generated from it can take many forms. Heckman \& Guskey (1998) questioned 1,010 graduates from a US university and found that for five years: $51 \%$ of the sample verbally supported the university, $41 \%$ of the sample financially contributed to the university, 39\% of the sample praised the university for others in social environments and 37\% of the sample encouraged friends or sons and daughters of friends to enter the university. In addition, a survey of 14,651 graduates from 67 global universities found that the Net Promoter Score (NPS) - an indicator of satisfaction - is positive (Graduate Management Admission Council, 2017), indicating that alumni would promote their degree and university to its familiars.

Another way to support the university in training professionals aligned with market needs is through programs that connect students with graduates, as they have much to teach to undergraduate students (Brudler \& Holtorf, 2018). According to Chi et al. (2012), alumni can act as mentors for current students, helping them especially by explaining career options and expectations.

Another relevant contribution is through the return of these graduates as part of the academic community of the home institution. According to $\mathrm{Li}$ et al. (2015), alumni are, on average, more likely to publish articles in high-impact journals compared to non-alumni faculty.

Also, from the institution's point of view, sending forms to map alumni is not a mere verification of data, because it generates resources that allow the adaptation of the educational institution (Schanaider, 2015). In addition, it is possible for the university to understand which factors in the alumni's profile impact their perception of the course. Pike (1994), for example, states that alumni who are most satisfied with their job have positive evaluations of their courses.

When considering benefits for Brazilian institutions, one can use the course evaluations obtained by alumni to perform the self-assessment proposed by the National Higher Education Assessment System (Universidade Estadual de Londrina, 2006). This practice becomes a differential for the university in an environment in which higher education institutions are more concerned with the regulatory effects arising from the evaluation than with the potential improvements raised by the analysis (Ribeiro, 2014). 
Alumni also benefit from this interaction, given that the university structure can enhance their professional activities, as well as enable engagement in academic activities that update their professional knowledge (UEL, 2006). In addition, the connection between alumni - which can be concretized through the educational institution - is also beneficial for the graduate who is in the job market (Tansey \& Yarrish, 2008).

A concrete example of these opportunities is presented by Cohen \& Malloy (2010). The authors compared the performance of "connected" firms - those with at least one partner who had studied at the same institution as the investor - with "unconnected" firms - those where there were no ties between the two parties. Investment fund managers not only focus heavily on connected companies but also benefit of significantly higher performance - around 7.8\% per year. Therefore, investors were not just betting against companies with which they had no university ties, they sought companies from their alumni network as the better choice to raise capital.

In general, it can be concluded that university mapping of alumni and alumni connection through a network have several advantages that benefit both parts. Therefore, the need to consolidate the monitoring of these professionals is important in the development of a culture of their insertion in the university institution (Instituto Nacional de Estudos e Pesquisas Educacionais Anísio Teixeira, 2015). For this consolidation to occur, there are different methods for conducting and updating the mapping activities.

\subsection{Alumni monitoring methods}

For the establishment of the continuous contact between the institution and the alumni, it is common for foreign universities to have a department that manages this relationship (Tansey \& Yarrish, 2008; Graduate Management Admission Council, 2017; Brudler \& Holtorf, 2018). The human and financial resources to maintain this networking are justified if the mapping systems and objectives are well structured (Brudler \& Holtorf, 2018).

Tansey \& Yarrish (2008) analyzed in detail the systems used by five US institutions to map alumni, including: i) online system integrated with Linkedin; ii) physical letters; iii) creation of email accounts specific to alumni; iv) annual networking meetings; and, v) sending cards periodically with the biography of the alumni to be updated, if needed, and returned to the university. Brudler \& Holtorf (2018) state that, in the studied institution, the trajectory of the alumni was tracked by sending emails and newsletters combined with the conduction of events and workshops for alumni.

The various ways of mapping alumni generate data that can be used to understand the profile of these professionals. Rattanamethawong et al. (2018) used the answers to group alumni in clusters by similarity. From this, it was possible to understand its characteristics and elaborate contribution strategies for the university in each segment. Chi et al. (2012) used data mining to provide alumni with activities that best fit their profile.

In the Brazilian context, studies in this sense have not yet reached an advanced level of development. According to INEP (2015), the Institutional Policy of Follow-up of the Alumni is still incipient. However, some universities have developed systems and analyzes to facilitate this process.

At the Federal University of Santa Catarina (UFSC), there is an alumni portal, where information about the alumni' professional life is gathered and course evaluations are received so that the university continuously improves and meets market demands (Silva \& Bezerra, 2015). Cunha (2012) presents a study of the profile of graduates in the Materials Engineering and Metallurgical Engineering courses at the University of São Paulo's (USP) Polytechnic School. In this study, the authors reported that USP did not have a unique alumni system and that is why the questionnaires were sent via social networks at the beginning. However, at the end of 2016, USP launched an integrated network called "Alumni USP" (Universidade de São Paulo, 2018) to bring together its alumni. The platform has access to the digital library collections, virtual diploma application, access to the G-Suite platform, contact of all USP alumni, professional opportunities "counter" with job vacancies made available by the students themselves, alumni and location tool to find the nearest alumni - which can be used to stimulate travel or congress networking (Universidade de São Paulo , 2018).

The State University of Londrina (UEL) has an Alumni Tracking Project that aims to improve the quality of education through contact with alumni of all courses. This project is carried out through the alumni registration at the Alumni Portal - an environment that has links to curricula, jobs, reports about courses and academic activities, as well as a space for communication between alumni and faculty. This registration is performed by a questionnaire that is compiled every three years (Universidade Estadual de Londrina, 2006).

From this section, it can be stated that there is an effort by universities to develop alumni tracking systems. In common among the actions presented is a step of registering the information of the former student, made from questionnaires and the use of systems to follow the trajectory of the alumni. Regardless of how to follow the path of the alumni, it is understood that the application of a questionnaire is the starting point to establish the connection and guide the form of the relationship between the graduate and the institution. 


\subsection{Competences of the production engineering professional}

As presented in section 2.1, the feedback generated by the alumni can guide the continuous development of the institution and support the prioritization of topics that will form part of the course strategy (Younis, 2002; Passow, 2012; Silva \& Bezerra, 2015). This assessment has relevance in undergraduate engineering courses, especially when considering the impacts of this professional's performance in the market. The versatility and scope of the actions of engineering professionals in relation to society enhance the importance of ensuring the quality of these students' education through monitoring and implementation of improvements (Dwek, 2012). Moreover, the proposed scientific studies on engineering education should pay attention to the question of who the engineers are (personal aspects) and what are their competences to determine the knowledge that should be aggregated during the course (Lucena et al., 2008).

In order to be in tune with society and the job market, one of the most comprehensive forms of curriculum organization and evaluation that higher education institutions have been adopting is the desired competences model of graduates' profile (Carvalho \& Tonini, 2017). The institutions and those responsible for the creation of the courses identify a set of competences and, from it, establish their curricula, disciplines, and contents aligned with the demands of the job market and of the society.

The concept of competence is associated with what is required in a given environment. According to the National Education Council "[...] professional competence means the personal ability to mobilize, articulate and put into action the knowledge, skills, attitudes, and values necessary for the efficient and effective performance of activities required by the nature of work and technological development [...]" (Brasil, 2002, art. $7^{\circ}$ ). The literature addresses competence as the set of knowledge, skills, attitudes and other characteristics that allow for a skillful performance (Passow, 2007; Jung \& Dörr, 2017).

Professional competences are mapped and established by national associations of specific knowledge areas with national education councils. In the Brazilian context, the Brazilian Association of Engineering Education (ABENGE) together with the Business Mobilization for Innovation of the National Confederation of Industry established this year eight competences that were approved in January 2019 by the Ministry of Education (Brasil, 2019a). Those competences must be developed by the engineering courses of the country. In addition, the document states that it is necessary to assess the technical competences required by each course, as there are several engineering ramifications.

Engineers' competences at the international level are defined by the Accreditation Board for Engineering and Technology (2012), widely disseminated in various engineering curriculum studies (Passow, 2007, 2012; Carvalho \& Tonini, 2017; Younis, 2002). The competences suggested by national and international regulators for engineering professionals overlap and incorporate different aspects of knowledge, skills, attitudes, context, and form. They combine more than one competency in the same sentence, making it difficult to analyze and prioritize items.

In addition, both associations do not separate competences between soft skills and hard skills, also known as transversal skills and technical skills (Santos et al., 2017; Lima et al., 2017). This view is important as these competences are developed in different ways. A report presented by Universium (2017) questioned 1,229 recruiters and managers about the soft skills sought by alumni. The study pointed to 21 competences: i) Reliability; ii) Responsibility; iii) Communication skills; iv) Positive attitude; v) Teamwork; vi) Troubleshooting; vii) Work ethics; viii) Adaptability; ix) Dedication; $x$ ) Integrity; xi) Flexibility; xii) Stress management; xiii) Time management; xiv) Proactivity; xv) Self-awareness; xvi) Empathy; xvii) Ability to make decisions; xviii) Creativity; xix) Innovation; xx) Critical thinking; xxi) Leadership and Management. Carvalho \& Tonini (2017) also established some competences from interviews with 17 engineers and made a list of 14 competences, among which 11 are defined in the National Curriculum Guidelines (Brasil, 2019b).

Considering that alumni are part of the job market, the assessment of the importance of these competences can contribute to the structuring of undergraduate courses, in terms of improvements to meet the demands of the job market (Passow, 2012). Passow (2012) found that there are four competences (teamwork, communication, data analysis, and problem-solving) that form a cluster of competences most important to engineers, regardless of the course and industry where the professional works. Research by Graduate Management Admission Council (2017) found that among the five most important skills for alumni, those related to interpersonal issues are the most important. Both studies find intermediate skills - meaning that the importance varies depending on the position of the alumni.

Among the engineers' competences, Jackson (2010) states that higher education institutions around the world are criticized for producing alumni with soft skills deficiencies, considered essential for greater productivity and innovation in the workplace. According to research by Universium (2017), 14,582 engineering students in Brazil state that the least developed social skills in the course are stress management, communication skills, and time 
management. Carvalho \& Tonini (2017), still claim that there is a lack of skills related to people management, while technical skills have been well developed.

From the identification of these competences, a gap can be established between the desired performance and the actual performance of that competence (Passow, 2012). Ranking gaps downwards can lead to improvements to institutions' programs as a way of prioritizing (Passow, 2012).

Considering the studies presented in this section, one can gauge the importance of conducting a competence's gap analysis in order to obtain detailed feedback from graduates. In addition, the mapping and evaluation of technical and soft skills have benefits for university institutions. By consolidating the result of this analysis, the university will be able to provide changes in undergraduate programs, as, according to Younis (2002), the faculty of departments has ultimate responsibility for curriculum development.

\section{Method}

Seeking to answer the research question, the study focused on a specific context - the undergraduate degree in Production Engineering at UFRGS - so that the procedure is characterized by a case study, following the procedure established by Alves-Mazzotti (2006). In the first, the procedures for developing the questionnaire were described and in the second, the research was applied. In the last stage, the results are presented through four analyzes: i) reliability analysis ii) the characterization of the alumni profile; iii) the identification of competence gaps; iv) the influence of the alumni's work sector in assessing the importance of each competence.

\subsection{Studied case}

The production engineering course at the Federal University of Rio Grande do Sul (UFRGS) was developed in 1999, the first class started in 2000 and had the first class graduated in 2004 (Universidade Federal do Rio Grande do Sul, 2015). The undergraduate course has achieved the full mark in the last edition (2017) of the National Student Performance Exam that evaluates undergraduate students' performance in relation to the syllabus, skills, and competences acquired in their education. However, until this study, there was no structured mapping of alumni or a formal alumni network, initiatives that can generate positive impacts for the institution and the course.

In this scenario, the Pedagogical Course Project (Universidade Federal do Rio Grande do Sul, 2015, p. 16) states that the alumni should be able to "[...] identify, prevent and solve problems related to the activities of design, operation, management and improvement of production and/or services systems, considering their human, economic, social and environmental aspects, with an ethical approach [...]". However, it is not known if this profile is in line with the current competences required by the job market.

\subsection{Research instruments}

The research instrument is a questionnaire divided into two sections: the first deals with the alumni profile and the second deals with the competences' gaps observed by the alumni. For the first part, a literature search about alumni mapping was done to identify the information that is required to understand the profile of these alumni. The database searched was Science Direct, using strings such as "Alumni”, "Alumni network" and "Tracking Alumni". A range of international papers was identified. After, another search for Brazilian papers was done, using Google Scholar and Lume (UFRGS database) and strings as "Egresso" (alumni), "Mapeamento de Egressos" (alumni mapping) and "Sistema de Mapeamento de Egresso" (alumni mapping system). Finally, all the studies abstracts were read and only the studies related to the alumni mapping were selected for in-depth analysis. Preference was also given to those materials that were awarded or published in journals. A number of 25 studies were initially selected and after an in-depth analysis, four were used to develop the first part of the research instrument.

The questionnaire developed comprise the alumni profile and the evaluation of the production engineer's competences. The questions related to the alumni profile (Table 1) were developed based on the studies of Silva \& Bezerra (2015), Universidade Estadual de Londrina (2006), Graduate Management Admission Council (2017) and Cunha (2012). Three of them had the same context (Brazilian universities) and the other (Graduate Management Admission Council, 2017) covered 300 universities.

The development of the second part of the questionnaire used the studies mentioned in the 2.3 section. As most articles referenced competences from ABET and ABENGE, these competences were considered. The competences mentioned at the UFRGS Production Engineering Pedagogical Project were also included. 
Table 1. Relationship between studies and questions for graduates.

\begin{tabular}{|c|c|c|c|c|c|}
\hline & QUESTIONS & $\begin{array}{c}\text { UFSC - Silva } \\
\& \text { Bezerra } \\
(2015)\end{array}$ & UEL (2006) & GMAC (2017) & $\begin{array}{l}\text { USP - Cunha } \\
\text { (2012) }\end{array}$ \\
\hline \multicolumn{6}{|c|}{ Personal Questions } \\
\hline 1 & Gender & $x$ & $x$ & $\mathrm{x}$ & \\
\hline 2 & Graduation year & $x$ & $\mathrm{x}$ & $x$ & $x$ \\
\hline 3 & Year of birth & $\mathrm{x}$ & & $\mathrm{x}$ & $\mathrm{x}$ \\
\hline 4 & City where was living before undergraduation & $\mathrm{x}$ & & $\mathrm{x}$ & \\
\hline 5 & City where is living now & $x$ & $x$ & $x$ & $x$ \\
\hline 6 & Has foreign language skills and uses them in the work environment & & & & $x$ \\
\hline \multicolumn{6}{|c|}{ Professional Questions } \\
\hline 7 & Performed extracurricular activities during the course. If so, which ones. & & $\mathrm{x}$ & & $\mathrm{x}$ \\
\hline 8 & Has attended or is attending a postgraduate course & & $x$ & $\mathrm{x}$ & \\
\hline 9 & Is employed & & $\mathrm{x}$ & $\mathrm{x}$ & \\
\hline 10 & Is working as a Production Engineer & $\mathrm{x}$ & $x$ & & \\
\hline 11 & Business sector of the company where works & $\mathrm{x}$ & & $x$ & $x$ \\
\hline 12 & Company size & & & $x$ & \\
\hline 13 & Company's department where is working & & & $x$ & $x$ \\
\hline 14 & Income range & $\mathrm{x}$ & $\mathrm{x}$ & $\mathrm{x}$ & $\mathrm{x}$ \\
\hline 15 & How satisfied is with the profession & & $\mathrm{x}$ & & \\
\hline \multicolumn{6}{|c|}{ Course Questions } \\
\hline 16 & $\begin{array}{l}\text { What is the chance of recommending the course to a friend (Net } \\
\text { Promoter Score) }\end{array}$ & & $x$ & $\mathrm{x}$ & \\
\hline 17 & Knowledge or competences most used as a Production Engineer & & $\mathrm{x}$ & $x$ & $x$ \\
\hline 18 & What else could be developed during the course & $x$ & $x$ & $x$ & \\
\hline
\end{tabular}

After having a preliminary list, a pre-test with alumni was performed to check if there were other competences that were not in the initial list.

A total of 23 competences were identified: 10 competences presented in the Course Pedagogical Project based on ABEPRO guidelines (Universidade Federal do Rio Grande do Sul , 2015), 12 competences suggested by Associação

Table 2. Competences.

\begin{tabular}{|c|c|c|}
\hline & COMPETENCE & SOURCE \\
\hline \multicolumn{3}{|c|}{ Technical skills } \\
\hline 1 & Be able to use mathematical and statistical tools to model production systems and assist decision making & UFRGS (2015) \\
\hline 2 & Be able to plan and manage productive systems & UFRGS (2015) \\
\hline 3 & Be able to plan and manage quality systems & UFRGS (2015) \\
\hline 4 & Be able to plan and manage health, safety and work organization & UFRGS (2015) \\
\hline 5 & $\begin{array}{l}\text { Be able to use performance indicators, costing systems and evaluate the economic and financial viability } \\
\text { of projects }\end{array}$ & UFRGS (2015) \\
\hline 6 & Be able to forecast and analyze customer requirements, managing product development or improvement & UFRGS (2015) \\
\hline 7 & $\begin{array}{l}\text { Be able to keep up with technological advances by organizing them and placing them at service of } \\
\text { companies and society's demands }\end{array}$ & UFRGS (2015) \\
\hline 8 & $\begin{array}{l}\text { Be able to predict the evolution of production scenarios by establishing business strategies that will } \\
\text { ensure long-term development }\end{array}$ & UFRGS (2015) \\
\hline 9 & Be able to manage and optimize the information flow in companies using the appropriate technologies & UFRGS (2015) \\
\hline 10 & $\begin{array}{l}\text { Be able to understand the interrelationship of production systems and the environment, managing the } \\
\text { use of resources and final waste disposal, paying attention to the sustainability requirement }\end{array}$ & UFRGS (2015) \\
\hline 11 & Ability to identify, formulate and solve problems & ABET (2012), ABENGE (2018) \\
\hline 12 & Pursuit continuous improvements in product and process performance & UFRGS (2015) \\
\hline 13 & Pursuit a constant search for rationalization of resource use & UFRGS (2015) \\
\hline \multicolumn{3}{|c|}{ Soft Skills } \\
\hline 14 & Ability to work in multidisciplinary teams & ABET (2012), ABENGE (2018) \\
\hline 15 & Professional responsibility & ABET (2012), ABENGE (2018) \\
\hline 16 & Ethic & ABET (2012), ABENGE (2018) \\
\hline 17 & Communication capacity & ABET (2012), ABENGE (2018) \\
\hline 18 & Knowledge of current issues & ABET (2012) \\
\hline 19 & Proactivity & UFRGS (2015) \\
\hline 20 & Innovative posture, being able to develop original and creative solutions & UFRGS (2015) \\
\hline 21 & Critical positioning sense & UFRGS (2015) \\
\hline 22 & Negotiation and conflict resolution & Pre-test \\
\hline 23 & Leadership & ABENGE (2018) \\
\hline
\end{tabular}


Brasileira de Educação em Engenharia (2018) and Accreditation Board for Engineering and Technology (2012), one competence (negotiation and conflict resolution) was added as suggestion of ten alumni through a pretest of the competence list. Table 2 present the final list of competences, divided into technical skills and soft skills.

The competences were evaluated based on a Likert scale. Based on the Universium report (UFRGS, 2018), the alumni assess each competence on a scale ranging from 1 to 5 , where 1 means "not important" and 5 "very important" by answering the question: "How important is that competence in your work environment?". After that, the alumni evaluate the same competence on a scale ranging from 1 to 5 , where 1 means "not developed" and 5 "was very well developed" by answering the question: "How much was this competence developed in the course? These data allow the development of an IPA (Importance-Performance Analysis) matrix.

\subsection{Data collection}

The inclusion criterion considered for the "alumni mapping" was the first category of alumni defined by Pena (2010, p. 29): those who "[...] have completed all curriculum credits and have already graduated, and, therefore, hold diplomas officially approved by the institution". As delimitation of the study, those graduates who have moved to other courses dropped out of courses or exceeded the time limits for completing credits for their course were excluded from the analysis.

Information about the alumni was asked to the UFRGS Production Engineering Undergraduate Commission (COMGRAD). During the 14 years graduating Production Engineers, around 700 people graduated. The COMGRAD has access to the data registered in the university system, such as the name and email address.

The questionnaires were sent by email or Linkedin to 700 graduates from 2004 to 2018 of the UFRGS Production Engineering course to improve the response rates. Tansey \& Yarrish (2008) argues that the highest response rate of graduates is achieved through various contact channels. The data collection was realized from May 13th, 2019 to May 31st, 2019, enabling time to answer the questions and also to send remind notes about the invitation to participate in the study. A total of 254 respondents returned complete answers, reaching a response rate of approximately 36.3 percent.

\subsection{Data analysis}

The first stage of data analysis was the reliability analysis, which became necessary since the research instrument was developed especially for this study and was not tested in previous studies. To this end, an analysis was performed using Cronbach's alpha, a method proposed by Cronbach (1951), which is used to verify the reliability of questionnaires (Tavakol \& Dennick, 2011). It is expected a Cronbach's alpha between 0.7 to 0.9 (Streiner, 2003). The test was applied using the NCSS software for the average grades related to the importance and the performance of the competences.

The technical competences present a satisfactory value according to the range proposed by Streiner (2003) ( 0.84 for importance and 0.88 for performance). The soft skills have Cronbach's alpha of 0.9 for importance and 0.92 for performance. A possible interpretation of this result is that soft skills may have some inherent dependence, for example, communication skills (Groysberg \& Slind, 2012) and ethics (Brown et al., 2005) are competences sometimes related to leadership.

Alumni profile data analysis was conducted applying descriptive statistical analysis. The competences' analysis was developed considering the importance and performance of each competence. To evaluate the gaps in competence development, the Importance-Performance Analysis (IPA) matrix proposed by Martilla \& James (1977) was used. The IPA matrix relates these two dimensions and visually clarifies which items should be given the most attention. From the matrix analysis, the most relevant competences gaps were scored, highlighting the most important with the worst-performing competences from the graduates' point of view. The value is calculated using the simple average of the importance and performance grades.

Finally, ANOVA (Analysis of Variance) was performed, to validate existing relationships (Passow, 2012). The aim of this analysis is to verify if the sector where the professional is inserted has an influence on the importance of the competences evaluated by him. Through this hypothesis, the data about the alumni profile were related to the competences. This analysis portrayed an intersection between the first and second part of the questionnaire, which was being treated separately until then.

\section{Results}

\subsection{Alumni profile}

The sample characterization is presented in Table 3. As can be seen, 94 (37\%) participants graduated between 2016 and 2018. A reason for that might be that this group has updated registrations and close academic experiences, facilitating their participation in the research. Therefore, it is necessary to consider this fact in the 


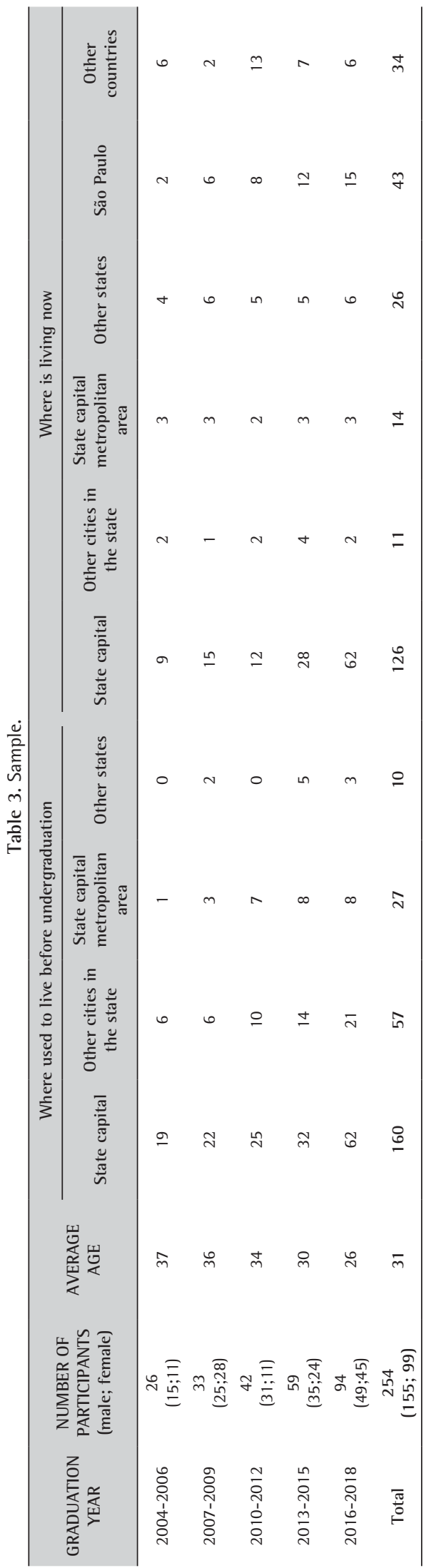


analysis of the consolidated values. Gender distribution seems to be in line with the estimated population of alumni. Among all alumni with whom the research application was established (573 people), 39\% were women and $61 \%$ were men.

Table 3 shows that the majority of the participants used to live in the state of Rio Grande do Sul, a fact that can change influenced by the modification in the undergraduate selection process (National High School Exam). Another point of attention is that 103 (out of 254) participants are now living out of the state.

Among the knowledge and the use of foreign languages in the work environment, we highlight the English, since 96\% have the knowledge and 76\% use it in the work environment. The data is in line with Cunha's (2012) survey, where 95\% of alumni have Advanced English. Spanish is the second most used language (21\%) but is the one where the lack of knowledge is missed in the work environment (19\%). An opportunity that arises from these data is the development of second and third languages during the undergraduate period.

Still, concerning the knowledge acquisition e extracurricular activities, 90\% of the participants joined one or more extracurricular activities. Several activities were listed and an extra internship was the most frequent (Table 4).

Table 4. Activities.

\begin{tabular}{|c|c|c|c|c|c|c|}
\hline Graduation year & 2004-2006 & 2007-2009 & 2010-2012 & 2013-2015 & 2016-2018 & Total \\
\hline Extra internship & $73 \%$ & $83 \%$ & $85 \%$ & $74 \%$ & $84 \%$ & $80 \%$ \\
\hline Junior Enterprise & $59 \%$ & $24 \%$ & $33 \%$ & $36 \%$ & $36 \%$ & $36 \%$ \\
\hline Undergraduate Research Fellow & $36 \%$ & $45 \%$ & $33 \%$ & $30 \%$ & $37 \%$ & $36 \%$ \\
\hline Academic mobility & $5 \%$ & $21 \%$ & $12 \%$ & $40 \%$ & $43 \%$ & $31 \%$ \\
\hline Production Engineering Student Union & $14 \%$ & $3 \%$ & $24 \%$ & $8 \%$ & $25 \%$ & $17 \%$ \\
\hline Engineering Student Union & $14 \%$ & $3 \%$ & $24 \%$ & $8 \%$ & $25 \%$ & $17 \%$ \\
\hline Other & $5 \%$ & $10 \%$ & $3 \%$ & $8 \%$ & $12 \%$ & $9 \%$ \\
\hline Administrative Scholarship & $0 \%$ & $0 \%$ & $3 \%$ & $6 \%$ & $16 \%$ & $8 \%$ \\
\hline Mentorship & $9 \%$ & $3 \%$ & $3 \%$ & $6 \%$ & $11 \%$ & $7 \%$ \\
\hline Engineering Athletic Team & $0 \%$ & $0 \%$ & $6 \%$ & $4 \%$ & $10 \%$ & $6 \%$ \\
\hline Double degree & $0 \%$ & $0 \%$ & $0 \%$ & $8 \%$ & $5 \%$ & $4 \%$ \\
\hline
\end{tabular}

Concerning graduate courses, between the years of 2004 and 2009 only 4\%-9\% of the participants have not taken (or are not taking) any graduate course. Among Specialization, Master Business Administration (MBA), Masters and Ph.D., MBA was the most required by the participants between 2004 and 2015. In the years of 2016 and 2018, the interest in Master has increased.

Data from the working situation were also collected and analyzed. Table 5, summarizes the employment condition, the size of the companies was the participants are working and their monthly income. For those who are unemployed, the sector, company size, and monthly income questions were regarded to their last job. Most of the participants are employed (93\%).

Table 5. Respondents employment distribution.

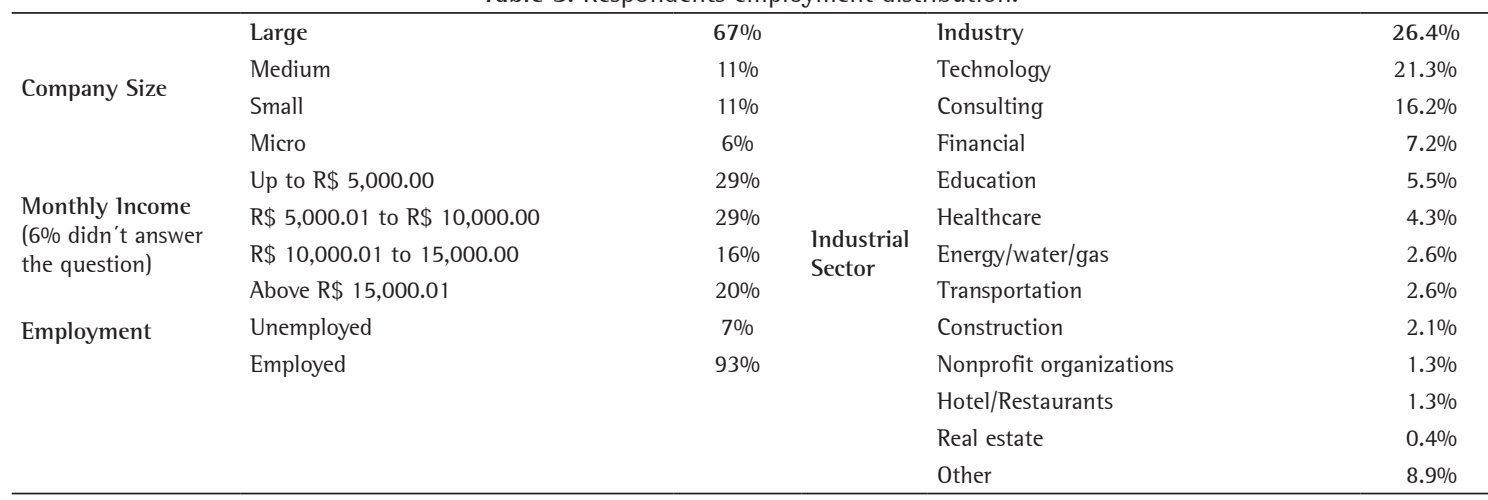


As expected for a Production Engineering course, the manufacturing industry is the sector that more employed the participants. The study by Cunha (2012) had even more interest in the industrial sector, whereas 52\% of graduates in Metallurgical and Materials Engineering work in the industrial sector. However, the industry sector represents 26.4\%, making room for a wide variety of sectors where alumni are present. Among the other areas of greater representation, we highlight the technology sector that has been very close to the industry (21.3\%). This sector includes mostly software companies such as Neogrid, Thoughtworks, Neo and E-Sales. This is a point of attention, since there are three technology-focused disciplines in the curricula (programming, information system and technology management), while the industrial sector is addressed in depth throughout the undergraduate course. The majority of the participants work in big size companies and 20\% of them have a monthly income above $\mathrm{R} \$ 15,000.00$, which is higher income than 99\% of the Brazilian workers (Zanlorenssi \& Ferreira, 2016).

The last question about working status was "How satisfied are you with your current profession?". Only 4\% are very dissatisfied or dissatisfied, while $79 \%$ satisfied or very satisfied.

\subsection{Identification of gaps in competence development}

An IPA matrix was done, considering the questions "How important is this competence in your work environment?" and "How much was this competence developed in the course?". Improvement opportunities can be identified, according to the IPA matrix result. Next, the matrix is presented along with a table that presents the arithmetic mean of the importance, performance and gap calculations (Table 6). The description of competences has been summarized for space reasons.

Table 6. IPA Matrix and Gaps details.

\begin{tabular}{|c|c|c|c|c|}
\hline Competence & Importance & Performance & Gap & Quadrant area \\
\hline \multicolumn{5}{|l|}{ Technical skills } \\
\hline 1. Statistical Tooling & 3.6 & 3.5 & -0.08 & Overdeveloped \\
\hline 2. Productive Systems & 3.8 & 3.8 & 0.01 & Overdeveloped \\
\hline 3. Quality Systems & 3.2 & 3.5 & 0.35 & Overdeveloped \\
\hline 4. Health and Safety & 2.5 & 2.8 & 0.35 & Low priority \\
\hline $\begin{array}{l}\text { 5. Use of indicators, costing systems and analysis of economic and financial } \\
\text { viability }\end{array}$ & 4.3 & 4.0 & -0.28 & Maintain \\
\hline 6. Predict and analyze customer requirements & 3.7 & 3.1 & -0.66 & Low priority \\
\hline 7. Follow technological advances & 4.0 & 2.6 & -1.42 & Low priority \\
\hline 8. Predict the evolution of productive scenarios & 3.8 & 2.9 & -0.87 & Low priority \\
\hline 9. Manage and optimize the information flow & 4.1 & 2.9 & -1.16 & Low priority \\
\hline $\begin{array}{l}\text { 10. Understand the relationship between production systems and the } \\
\text { environment }\end{array}$ & 2.7 & 2.8 & 0.09 & Low priority \\
\hline 11. Problem solutions & 4.8 & 4.0 & -0.82 & Maintain \\
\hline 12. Continuous improvement & 4.5 & 3.9 & -0.57 & Maintain \\
\hline 13. Rationalization of resources & 4.0 & 3.6 & -0.41 & Overdeveloped \\
\hline \multicolumn{5}{|l|}{ Soft Skills } \\
\hline 14. Teamwork & 4.6 & 3.4 & -1.18 & Maintain \\
\hline 15. Professional Responsibility & 4.8 & 3.4 & -1.35 & Maintain \\
\hline 16. Ethics & 4.7 & 3.4 & -1.29 & Maintain \\
\hline 17. Communication skills & 4.7 & 3.1 & -1.65 & Prioritize \\
\hline 18. Knowledge in current issues & 4.2 & 2.7 & -1.46 & Prioritize \\
\hline 19. Proactivity & 4.7 & 3.3 & -1.34 & Maintain \\
\hline 20. Innovative posture, being able to develop original and creative solutions & 4.4 & 3.0 & -1.43 & Prioritize \\
\hline 21. Critical positioning sense & 4.6 & 3.3 & -1.22 & Maintain \\
\hline 22. Negotiation and conflict resolution & 4.5 & 2.4 & -2.08 & Prioritize \\
\hline 23. Leadership & 4.4 & 2.7 & -1.75 & Prioritize \\
\hline
\end{tabular}

Also, for each competence, an action is suggested from the quadrant that it is in the IPA Matrix. (see Figure 1). The quadrants were defined from the mean value of importance and performance and are characterized as (Martilla \& James, 1977, p. 78): i) Concentrate here - high importance, low performance: requires immediate attention for improvement and are major weaknesses; ii) Keep up with the good work - high importance, high performance: indicate opportunities for achieving or maintaining competitive advantage and are major strengths; 
ii) Low priority - low importance, low performance: are minor weaknesses and do not require additional effort and, iv) Possible overkill - low importance, high performance: indicate that business resources committed to these attributes would be overkill and should be deployed elsewhere.

Thus, in Figure 1, the upper left quadrant has competences with greater than average importance and with less than average performance, so these points should be prioritized. Most of the skills that should be prioritized in future actions to improve the course are related to soft skills such as "Negotiation and conflict resolution", "Leadership", "Communication skills" and "Innovative posture". The upper right quadrant has competences with high performance and importance scores so that actions must be maintained. Competences as "Problem solutions", "Continuous improvement" and "Use of indicators, costing systems and analysis of economic and financial viability" are examples of important competences that have been well developed by the course. The lower quadrants are of low importance and should not be prioritized. The lower right quadrant can be considered an unnecessary resource allocation since those competences are less important than the average and have a performance larger than the performance average. The competence of "ability to plan and manage quality systems" is an example of overdeveloped competence.

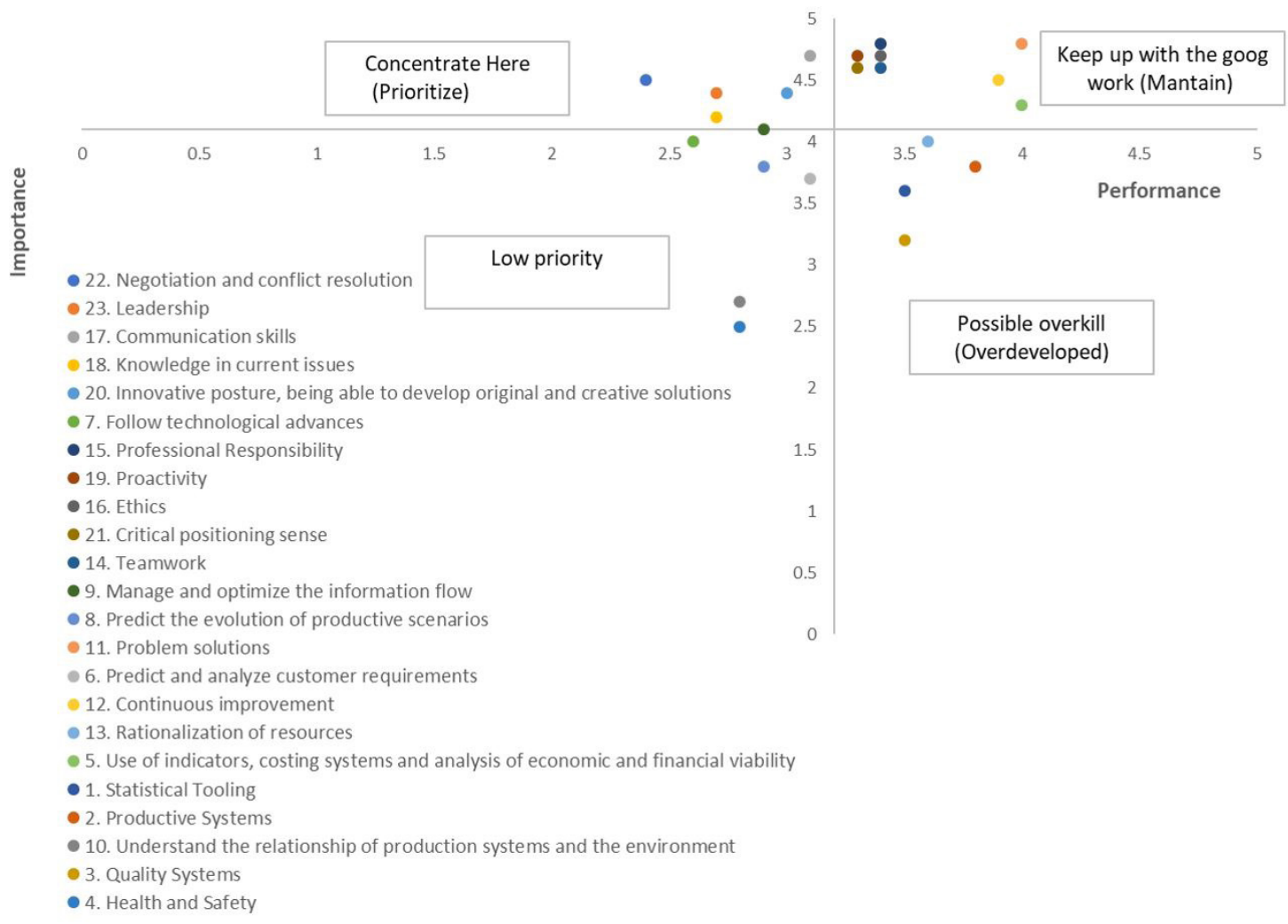

Figure 1. Importance - Performance Matrix for production engineer profile competences.

Initially, it can be seen that any competence has an average performance score below 2, which means that none of them are very underdeveloped in the course. The importance scores also didn't have an average below 2 , which indicates that those competences some relevance in the market.

The gaps presented low values - the largest gap is 2.1 so that the discrepancy between what is required in the market and what is developed in the course does not reach high levels. This result is in line with the analysis of the student profile, once there is high satisfaction with the course, high salaries and high satisfaction with the profession. However, there is still the opportunity to develop competences whose importance is greater than 4.1 and performance is below 3.2, located in the upper left quadrant of the matrix.

Finally, as seen in the literature review (Passow 2012; Graduate Management Admission Council, 2017; Santos et al., 2017; Lima et al., 2017), the relevance of soft skills are highlighted. Although the most important competence is "Problem Solving", the other competences in the importance ranking are soft skills, such as 
Professional responsibility, Ethics, Communication skills, Proactivity, and Teamwork. No competence in this group has an excess of resources or low priority. In addition, the biggest gaps are also present in softs skills, the result that is aligned with the results of Universium (2017) and Carvalho \& Tonini (2017) study. Therefore, it is suggested that those involved in the course management continue to look for ways to reinforce the development of these competences. Furthermore, the biggest gap was in "Negotiation and Conflict Resolution", competence suggested during the data collection instrument pretest and not found in the literature review.

\subsection{Professional sector influence in assessing the importance of competences}

The One way ANOVA method was applied to verify if the graduation sector influences the importance score of each of the competences. For this, we considered the four sectors that contained the largest number of alumni - industry, technology, consulting and the financial sector. Numbers were assigned to these sectors and compared to the importance scores assessed by the alumni, and an ANOVA was performed for each different competence.

All 23 competences were significant for a p-value below 0.05 . From this result, it is possible to verify that the sector of influence has an influence on the importance of all the evaluated competences. This is a different result than expected since soft skills were ranked very high and it was thought that this group of skills was equally important across sectors, as observed in the study by Passow (2012). Average values by sector can be seen in Table 7.

Table 7. Average values by sector.

\begin{tabular}{|c|c|c|c|c|}
\hline Competences & Industry & Technology & Consulting & Financial market \\
\hline 1. Statistical Tooling & 3.53 & 3.72 & 4.08 & 3.53 \\
\hline 2. Productive Systems & 3.95 & 3.74 & 4.13 & 3.35 \\
\hline 3. Quality Systems & 3.63 & 3.02 & 3.16 & 2.65 \\
\hline 4. Health and Safety & 3.23 & 1.98 & 2.18 & 1.88 \\
\hline $\begin{array}{l}\text { 5. Use of indicators, costing systems and analysis of economic and financial } \\
\text { viability }\end{array}$ & 4.48 & 4.12 & 4.63 & 4.35 \\
\hline 6. Predict and analyze customer requirements & 3.42 & 4.26 & 3.92 & 3.82 \\
\hline 7. Follow technological advances & 3.82 & 4.58 & 4.05 & 3.88 \\
\hline 8. Predict the evolution of productive scenarios & 4.02 & 3.78 & 4.24 & 3.41 \\
\hline 9. Manage and optimize the information flow & 4.27 & 4.18 & 4.18 & 3.59 \\
\hline $\begin{array}{l}\text { 10. Understand the relationship between production systems and the } \\
\text { environment }\end{array}$ & 3.40 & 2.32 & 2.61 & 1.76 \\
\hline 11. Problem solutions & 4.90 & 4.90 & 4.84 & 4.65 \\
\hline 12. Continuous improvement & 4.66 & 4.62 & 4.68 & 4.47 \\
\hline 13. Rationalization of resources & 4.47 & 3.78 & 4.26 & 3.35 \\
\hline 14. Teamwork & 4.81 & 4.74 & 4.76 & 4.29 \\
\hline 15. Professional Responsibility & 4.92 & 4.82 & 4.87 & 4.65 \\
\hline 16. Ethics & 4.87 & 4.76 & 4.89 & 4.41 \\
\hline 17. Communication skills & 4.81 & 4.72 & 4.84 & 4.18 \\
\hline 18. Knowledge in current issues & 4.15 & 4.28 & 4.42 & 4.00 \\
\hline 19. Proactivity & 4.76 & 4.76 & 4.76 & 4.47 \\
\hline 20. Innovative posture, being able to develop original and creative solutions & 4.45 & 4.60 & 4.47 & 4.29 \\
\hline 21. Critical positioning sense & 4.68 & 4.64 & 4.79 & 4.18 \\
\hline 22. Negotiation and conflict resolution & 4.65 & 4.56 & 4.66 & 3.82 \\
\hline 23. Leadership & 4.68 & 4.46 & 4.71 & 4.06 \\
\hline
\end{tabular}

\section{Conclusions}

The present article had three initial objectives: i) map the alumni profile through personal and professional information; ii) identify gaps in the perception of alumni between the importance of production engineer competences and how much those competences were developed during the course; iii) correlate profile information of alumni with the gaps of the competences evaluated by them. These objectives were achieved through the application of a descriptive questionnaire that included personal, professional, satisfaction and competence assessment questions. The analysis of the answers to the questionnaire was quantitative and had Cronbach's alpha application through NCSS, besides simple graphs, IPA matrix, and ANOVA. 
From the applied research instrument, several conclusions were obtained. In the profile analysis, the following stand out: i) the importance of the English language in the job market; ii) the concentration of new students from the southern region of Brazil; iii) the diversification of sectors in which alumni are working, with increased insertion in the technology sector; iv) high salaries, but significant disparities between female and male; v) high satisfaction with the course and the profession; vi) High-performance scores, which indicates a good development of competences in the course; vii) the importance of soft skills, which have higher grades and greater gaps. Finally, through ANOVA, it was verified that there is an influence of the sector in which the alumni work in the evaluation of the importance of competences.

Among the limitations of the study is the fact that the sample focuses mainly on alumni who graduated between 2016 and 2018. Another issue, which was reported by alumni who graduated a long time ago, is the assessment of competency development by the course, given the difficulty in identifying at what point in life a particular competence was developed.

In future studies, it would be interesting to apply a similar questionnaire to other UFRGS courses and alumni from other universities and countries, providing comparative analysis that enhances results between courses. Another option would be to systematize this relationship with the alumni of Production Engineering from UFRGS and from there understand how the suggestions proposed by them can be contemplated in PMG, using the results on the competences for future curriculum updates. During the application of the questionnaire, there was a strong engagement of alumni - observed even by the number of answers (254), which indicates a strong engagement of these professionals with the improvement of the course. This highlights the practical contributions of this paper but is worth nothing also the theoretical contribution of the paper on the development of the questionnaire to collect data about alumni, to evaluate the importance e development of the competences and the relationship of the market sector and the need of certain competences.

\section{References}

Accreditation Board for Engineering and Technology - ABET. (2012). Criteria for accrediting engineering programs. Baltimore: ABET.

Alves-Mazzotti, A. J. (2006). Usos e abusos dos estudos de caso. Cadernos de Pesquisa, 36(129), 637-651. http://dx.doi.org/10.1590/ S0100-15742006000300007.

Associação Brasileira de Educação em Engenharia - ABENGE. (2018). Proposta de Diretrizes Curriculares Nacionais para o curso de Engenharia. Brasília: ABENGE.

Associação Brasileira de Engenharia de Produção - ABEPRO. (1998). Engenharia de Produção: grande área e diretrizes curriculares. Porto Alegre: ABEPRO.

Borchardt, M., Vaccaro, G. L. R., Azevedo, D., \& Ponte Junior, J. (2009). 0 perfil do engenheiro de produção: a visão de empresas da região metropolitana de Porto Alegre. Production, 19(2), 230-248. http://dx.doi.org/10.1590/S0103-65132009000200002.

Brasil. Conselho Nacional de Educação. (2002, 23 de dezembro). Resolução CNE/CP3, de 18 de dezembro de 2002. Institui as Diretrizes Curriculares Nacionais Gerais para a organização e o funcionamento dos cursos superiores de tecnologia. Diário Oficial da República Federativa do Brasil. Seção 1, 162.

Brasil. Ministério da Educação - MEC. (2019a). Curso de graduação em engenharia. Brasília: MEC.

Brasil. Ministério da Educação. (2019b, 26 de abril). Resolução n 2, de 24 de abril de 2019. Institui as Diretrizes Curriculares Nacionais do Curso de Graduação em Engenharia. Diário Oficial da República Federativa do Brasil. Seção 1, 43.

Brown, M. E., Treviño, L. K., \& Harrison, D. A. (2005). Ethical leadership: a social learning perspective for construct development and testing. Organizational Behavior and Human Decision Processes, 97(2), 117-134. http://dx.doi.org/10.1016/j.obhdp.2005.03.002.

Brudler, E., \& Holtorf, H. (2018). On the alumni networking of the Postgraduate Programme Renewable Energy at the University of Oldenburg. Solar Energy, 173, 691-695. http://dx.doi.org/10.1016/j.solener.2018.07.062.

Carvalho, L. D. A., \& Tonini, A. M. (2017). Uma análise comparativa entre as competências requeridas na atuação profissional do engenheiro contemporâneo e aquelas previstas nas diretrizes curriculares nacionais dos cursos de Engenharia. Gestão \& Produção, 24(4), 829-841. http://dx.doi.org/10.1590/0104-530x1665-16.

Chi, H., Jones, E. L., \& Grandham, L. P. (2012). Enhancing mentoring between alumni and students via smart alumni system. Procedia Computer Science, 9, 1390-1399. http://dx.doi.org/10.1016/j.procs.2012.04.153.

Cohen, L., \& Malloy, C. J. (2010). The power of alumni networks. Harvard Business Review, 88, 10.

Cronbach, L. J. (1951). Coefficient alpha and the internal structure of tests. Psychometrika, 16(3), 297-334.

Cunha, F. (2012). Coleta, desenvolvimento e análise do perfil dos egressos de graduação em engenharia de materiais e metalúrgica da escola Politécnica da USP [Trabalho de conclusão]. Escola Politécnica, Universidade de São Paulo, São Paulo.

Deros, B. M., Mohamed, A., Mohamed, N., \& Ihsan, A. K. A. M. (2012). A study of alumni feedback on outcome based education in the Faculty of Engineering \& Built Environment, Universiti Kebangsaan Malaysia. Procedia: Social and Behavioral Sciences, 60, 313-317. http://dx.doi.org/10.1016/j.sbspro.2012.09.385.

Dwek, M. (2012). Por uma renovação da formação em engenharia: questões pedagógicas e curriculares do atual modelo brasileiro de educação em engenharia (dissertação). Universidade Federal do Rio de Janeiro, Rio de Janeiro.

Graduate Management Admission Council - GMAC. (2017). Alumni Perspectives Survey Report 2017. Reston: GMAC.

Groysberg, B., \& Slind, M. (2012). Leadership is a conversation. Harvard Business Review, 90(6), 76-84, 144. PMid:22741420. 
Heckman, R., \& Guskey, A. (1998). The relationship between alumni and university: toward a theory of discretionary collaborative behavior. Journal of Marketing Theory and Practice, 6(2), 97-112. http://dx.doi.org/10.1080/10696679.1998.11501799.

Instituto Nacional de Estudos e Pesquisas Educacionais Anísio Teixeira - INEP. (2015). Política Institucional de Integração e de Avaliação do Egresso na Melhoria da IES. Brasília: Diretoria de Avaliação da Educação Superior INEP/MEC.

Jackson, D. (2010). An international profile of industry-relevant competencies and skill gaps in modern graduates. International Journal of Management Education, 8(3), 29-58. http://dx.doi.org/10.3794/ijme.83.288.

Jung, C. F. \& Dörr, C. R. B. (2017). Método para elaboração de programas de disciplinas a partir de competências: habilidades, atitudes e conhecimentos. In Anais do XVII Colóquio Internacional de Gestão Universitária (pp. 1-5). Mar Del Plata: Universidad Nacional de Mar Del Plata.

Li, F., Miao, Y., \& Yang, C. (2015). How do alumni faculty behave in research collaboration? An analysis of Chang Jiang Scholars in China. Research Policy, 44(2), 438-450. http://dx.doi.org/10.1016/j.respol.2014.09.002.

Lima, R. M., Mesquita, D., Rocha, C., \& Rabelo, M. (2017). Defining the Industrial and Engineering Management Professional Profile: a longitudinal study based on job advertisements. Production, 27(No. spe), e20162299. https://doi.org/10.1590/0103-6513.229916.

Lucena, J., Downey, G., Jesiek, B., \& Elber, S. (2008). Competencies beyond countries: the re-organization of engineering education in the United States, Europe, and Latin America. Journal of Engineering Education, 97(4), 433-447. http://dx.doi.org/10.1002/j.2168-9830.2008. tb00991.x.

Martilla, J. A., \& James, J. C. (1977). Importance-performance analysis. Journal of Marketing, 41(1), 77-79. http://dx.doi. org/10.1177/002224297704100112.

Passow, H. J. (2007). What competencies should engineering programs emphasize? A meta-analysis of practitioners' opinions informs curricular design. In Proceedings of the 3rd International CDIO Conference (pp. 1-36). Cambridge: MIT.

Passow, H. J. (2012). Which ABET competencies do engineering graduates find most important in their work? Journal of Engineering Education, 101(1), 95-118. http://dx.doi.org/10.1002/j.2168-9830.2012.tb00043.x.

Pena, M. D. C. (2010). Acompanhamento de egressos: uma análise conceitual e sua aplicação no âmbito educacional brasileiro. Educação \& Tecnologia, 5(2), 25-30.

Pike, G. R. (1994). The relationship between alumni satisfaction and work experiences. Research in Higher Education, 35(1), 105-123. http://dx.doi.org/10.1007/BF02496664.

Rattanamethawong, N., Sinthupinyo, S., \& Chandrachai, A. (2018). An innovation model of alumni relationship management: Alumni segmentation analysis. Kasetsart Journal of Social Sciences, 39(1), 150-160. http://dx.doi.org/10.1016/j.kjss.2017.02.002.

Ribeiro, J. L. L. S. (2014). SINAES: o que aprendemos acerca do modelo adotado para avaliação do ensino superior no Brasil. Avaliação: Revista da Avaliação da Educação Superior, 20(1), 143-161.

Santos, P. F., Simon, A. T., Guimarães, G. E., Amorim, M., \& Vieira Junior, M. (2017). Analyzing the competences of production engineering graduates: an industry perspective. Production, 27(0). http://dx.doi.org/10.1590/0103-6513.005317.

Schanaider, A. (2015). Sistema de mapeamento dos egressos. Revista do Colégio Brasileiro de Cirurgiões, 42(6), 413-417. http://dx.doi. org/10.1590/0100-69912015006011. PMid:26814995.

Silva, J. M., \& Bezerra, R. O. (2015). Sistema de acompanhamento dos egressos aplicado na Universidade Federal de Santa Catarina. Revista Gestão Universitária na América Latina-GUAL, 8(3), 1-15.

Streiner, D. L. (2003). Starting at the beginning: an introduction to coefficient alpha and internal consistency. Journal of Personality Assessment, 80(1), 99-103. http://dx.doi.org/10.1207/S15327752JPA8001_18. PMid:12584072.

Tansey, J., \& Yarrish, J. (2008). Tracking alumni: strategies for collecting and updating personal and professional information, students affair leadership council. Washington: The Advisory Board Company. Retrieved in 2008, November 1, from https://www.etsu.edu/125/ documents/tracking-alumni.pdf

Tavakol, M., \& Dennick, R. (2011). Making sense of Cronbach's alpha. International Journal of Medical Education, 2, 53-55. http:// dx.doi.org/10.5116/ijme.4dfb.8dfd. PMid:28029643.

Universidade de São Paulo - USP. (2018). Alumni USP: Uma plataforma para reunir ex-alunos da Universidade. Retrieved in 2018, November 1, from http://www.alumni.usp.br/

Universidade Estadual de Londrina - UEL. (2006). Acompanhamento do Egresso (No. 5, Cadernos de Avaliação Institucional). Londrina: Pró-reitoria de planejamento.

Universidade Federal do Rio Grande do Sul - UFRGS. (2015). Projeto Pedagógico da Graduação em Engenharia de Produção. Porto Alegre: Departamento de Engenharia de Produção e Transportes, Escola de Engenharia, Universidade Federal do Rio Grande do Sul.

Universidade Federal do Rio Grande do Sul - UFRGS. (2018). Universium, Investigação de talento - Pesquisa Universium 2018: relatório. Porto Alegre: UFRGS.

Universium. (2017). Employers \& Gen Y: the soft skills that get you hired. USA: Universium.

Younis, N. (2002). Impact of alumni feedback on the curriculum. In Proceedings of the 2002 American Society for Engineering Education Annual Conference \& Exposition (Vol. 7, No. 1). Monteal: American Society for Engineering Education.

Zanlorenssi, G., \& Ferreira, L. (2016). O seu salário diante da realidade brasileira. NEXO. Retrieved in 2019, November 1, from https:// www.nexojornal.com.br/interativo/2016/01/11/0-seu-sal\%C3\%A1rio-diante-da-realidade-brasileir 